\title{
BIOLOGICAL WATER QUALITY ASSESSMENT OF THE WHITE- CLAWED CRAYFISH HABITAT BASED ON MACROINVERTEBRATE COMMUNITIES: USEFULNESS FOR ITS CONSERVATION
}

\author{
F. GRANDJEAN (1), J. MOMON (2), M. BRAMARD (2)
}

(1) Université de Poitiers, Laboratoire de Génétique et Biologie des Populations de Crustacés, UMR 6556, 40, avenue du Recteur Pineau, 86022 Poitiers Cedex, France.

(2) Délégation Régionale du Conseil Supérieur de la Pêche, 112, Faubourg de la Cueille, 86000 Poitiers, France.

E-mail: frederic.grandjean@univ-poitiers.fr

Reçu le 11 septembre 2003

Accepté le 8 janvier 2004

Received September 11, 2003

Accepted January 8, 2004

\begin{abstract}
A survey of the macroinvertebrates of three brooks harbouring the white-clawed crayfish was conducted in Haute-Vienne department (France). Its aim was to increase our understanding of these ecosystems to help the conservation of $A$. pallipes. These brooks run through pastoral areas with well-developed riparian vegetation, which offers an important shade. Water temperature, dissolved oxygen concentration, $\mathrm{pH}$, and conductivity fell within the ranges found for this species. A total of 34, 31, 29 taxa and 1502, 1364 , 2707 individuals of macrobenthos were collected in Holme, Besque and Bellecombe streams, respectively. Results showed good to very good water quality with IBGN scores ranging from 15 (Bellecombe) to 17 (Holme and Besque), reflecting a limited impact of the anthropogenic disturbances. Taxa diversity were high for Holme and Besque with Shannon index around 3.2, translating a great heterogeneity of habitat and an equilibrated faunal community. Bellecombe showed a limited diversity with Shannon index of 1.42, resulting from the presence of numberous Chironomidae. This brook suffers probably weak organic pollution which could be related to the low water flow observed during the sampling. The similarity test according to Jaccard index showed high percentage of common taxa among ETP (Ephemeroptera-Trichoptera-Plecoptera) between all sites. The high similarity of benthic macroinvertebrate communities could be an useful criteria to identify brooks for restocking purpose.
\end{abstract}

Keywords: Austropotamobius pallipes, macroinvertebrates, biotic indices, rivers, water quality.

ÉTUDE DE LA QUALITÉ BIOLOGIQUE DE L'EAU DE L'HABITAT DE L'ÉCREVISSE À PATTES BLANCHES, BASÉE SUR LES COMMUNAUTÉS DE MACROINVERTÉBRÉS : UTILITÉ POUR SA CONSERVATION

\section{RÉSUMÉ}

Une étude des macroinvertébrés de trois cours d'eau hébergeant des populations d'écrevisse à pattes blanches a été menée dans le département de la Haute-Loire (France). Son but est d'améliorer notre compréhension de ces écosystèmes pour aider à 
la conservation d'A. pallipes. Ces ruisseaux traversent des zones pastorales, bordés par une ripisylve bien développée qui offre un ombrage important. Les valeurs concernant la température de l'eau, la concentration d'oxygène dissous, le $\mathrm{pH}$ et la conductivité se placent dans la gamme de tolérance de cette espèce. Un total de 34, 31, 29 taxons et 1502, 1364, 2707 individus ont été collectés pour les stations d'Holme, de Besque et de Bellecombe, respectivement. Les résultats ont montré une qualité de l'eau de bonne a très bonne avec des notes IBGN comprises entre 15 (Bellecombe) et 17 (Holme et Besque), reflétant un impact limité des perturbations d'origine anthropique. La diversité taxonomique est forte pour les stations d'Holme et Besque avec un indice de Shannon autour de 3,2 traduisant une grande hétérogénéité d'habitat et un peuplement faunistique équilibré. Bellecombe a montré une diversité limitée avec un indice de Shannon de 1,42, résultant du nombre important de Chironomidae. Ce ruisseau souffre probablement d'une légère pollution organique laquelle pourrait être reliée aux faibles vitesses de courant observées pendant l'échantillonnage. Les tests de similarité selon l'indice de Jaccard ont montré de forts pourcentages de taxons en commun parmi les ETP (EphémèresTrichoptères-Plécoptères) entre tous les sites. Cette forte similarité des communautés de macroinvertébrés benthiques pourrait être un critère utile pour identifier des ruisseaux en vue de repeuplement.

Mots-clés : Austropotamobius pallipes, macroinvertébrés, indices biotiques, rivière, qualité d'eau.

\section{INTRODUCTION}

The white-clawed crayfish Austropotamobius pallipes lives in clean, well-oxygenated calcium-rich water that do not contains too much sediment. They are considered to be sensitive to physical and chemical alterations of their habitat (VERNEAUX et al., 1983). As a result of degradation of water and habitat quality, $A$. pallipes, which was formely widespread in Europe and particularly in France, is now confined to headwater with welldeveloped riparian cover (VIGNEUX, 1997 ; HOLDICH, 2002). For example, among the 178 populations of $A$. pallipes recorded within Poitou-Charentes rivers system (France) in 1978, only 38 persist at the present time (Authors, unpublished data). Because of its decline, $A$. pallipes has been listed as vulnerable on the red list of threatened animals of the International Union for the Conservation of Nature and Natural Resources (I.U.C.N.) (BAILLIE and GROOMBRIDGE, 1996), and is also listed in annexes II and IV of European Community Directives for the Conservation of Natural Habitats and Wild Flora and Fauna (92/43/EEC and 97/62/EU) as a species requiring special conservation measures. Among the conservation measures listed by DIEGUEZ-URIBEONDO et al. (1997), the preservation and the re-establishment of the populations of $A$. pallipes within its habitat range is a necessary prerequite to its conservation. This requires a good knowledge of crayfish habitat in terms of water quality but also in terms of ecological condition. Indeed, knowledge of physical and chemical characteristics provides little information about the ecological state of rivers and does not provide a consistent assessment of river condition. Characterizing aquatic ecosystems using biological criteria enables a more robust interpretation of ecological condition than using simple water chemical quality alone (LAZARIDOUDIMITRIADOU et al., 2000). In freshwater ecosystems, a wide variety of biotic groups is used for biomonitoring the state of ecosystems. According to MANDAVILLE (2000), the macroinvertebrates are the most popular group. There are many reasons which explain this craze. Benthic macroinvertebrates are found in all aquatic environments from thermal springs to salt lakes. These communities include worms, snails, water mites, leeches, small crustacean, and insect larvae, inhabit the sediment or live on or in other bottom substrates in the aquatic environment (KLEMM et al., 1990). They are an important food source for aquatic predator such as fish, amphibians and crayfish. They exploit the physical characteristics of streams to obtain their food (MERITT and CUMMINS, 1996) and 
affect nutrient availability and plant productivity in the water. Their community structure responds to water quality perturbations in a predictable fashion. The presence of some species is indicative of clean, unpolluted waters, while other species thrive in polluted waters. Because of these characteristics, benthic invertebrates are commonly used to evaluate the ecological integrity of streams and as indicators of water quality (BARBOUR et al., 1999).

Recently, a number of studies have evaluated the suitability of macroinvertebrates to characterize the water quality and habitat of $A$. pallipes brooks by the use of specific French biotic index called IBGN (see materials \& methods) (GRANDJEAN et al., 1996, 2000, 2001; BROQUET et al., 2002). They reported that crayfish, formely considered as bio-indicator, can live in brooks having sub-optimal water quality.

In this study, the taxonomic composition of benthic macroinvertebrates in three brooks harbouring $A$. pallipes is determined. The aim of study is to help for its conservation in three ways (1) to watch the evolution of crayfish sites over time by monitoring of the global water quality of these ones; (2) to prevent the risk of disappearance of crayfish population in pointing out a habitat degradation and (3) to collect informations which could be used to select suitable habitat in restocking plans in a given ecoregion.

\section{MATERIALS AND METHODS}

\section{Physical characteristics of studied sites}

Samples were collected in three brooks that runs through the Haute-Loire department. The crayfish sites were in first order streams located less than $3 \mathrm{~km}$ from the stream source (Table I). A description of few physical and chemical parameters of each sites was made (habitat description, water temperature, dissolved oxygen concentration, $\mathrm{pH}$, and conductivity).

\section{Table I}

Main physical and chemical parameters of studied sites.

\section{Tableau I}

Principaux paramêtres physiques et chimiques des sites étudiés.

\begin{tabular}{lccc}
\hline & Holme & Besque & Bellecombe \\
\hline Stream order & $\mathrm{I}$ & $\mathrm{I}$ & $\mathrm{I}$ \\
Depth $(\mathrm{m})$ & $0.05-0.40$ & $0.05-0.60$ & $0.05-0.40$ \\
Width mean $(\mathrm{m})$ & 2.3 & 2.28 & 2.9 \\
Water temperature $\left({ }^{\circ} \mathrm{C}\right)$ & 12.4 & 14.1 & 12.9 \\
Bryophytes & present & present & present \\
Sand & $20 \%$ & $60 \%$ & $10 \%$ \\
Gravels & $10 \%$ & $10 \%$ & $10 \%$ \\
Stones & $70 \%$ & $30 \%$ & $70 \%$ \\
Aquatic macrophytes & none & none & none \\
Canopy cover & $50-80 \%$ & $50-80 \%$ & $50-80 \%$ \\
Fine sediment "Mud" & none & none & $10 \%$ \\
Surrounding & pastoral area & pastoral area & pastoral area \\
\hline
\end{tabular}




\section{Macroinvertebrate sampling}

Sampling followed the I.B.G.N. protocol (AFNOR 1992). Eight samples of macroinvertebrates were taken at each of the 3 sites using a standard Surber sampler (surface $500 \mathrm{~cm}^{2}$, mesh size $500 \mu \mathrm{m}$ ) according to the protocol established by VERNEAUX et al. (1983). Samples were placed in a plastic bag and preserved in $10 \%$ formaldehyde. The habitats at each site were sampled according to a reference sampling table taking into account the nature of the substrate and water speed (Table II). Substrates are classified according to their ability to contain organisms (Table II) from bryophytes first, to algae and clay, last. The order of sampling followed the substrate list order. In the laboratory, the animals were sorted using a $500 \mu \mathrm{m}$ mesh sieve and identified taxonomically to family level (apart from Hydrozoa, Hydracarina and Oligochaeta).

\section{Table II}

Sampling protocol by the IBGN method. Eight samples are taken per site: 1, Holme; 2, Bellecombe and 3, Besque.

\section{Tableau II}

Grille d'échantillonnage de la méthode IBGN. 8 prélèvements par site sont effectués : 1, station d'Holme ; 2 , station de Bellecombe et 3 , station de Besque.

\begin{tabular}{|c|c|c|c|c|}
\hline \multirow{2}{*}{\multicolumn{2}{|c|}{ SUBSTRATES }} & \multicolumn{3}{|c|}{$\begin{array}{l}\text { Superficial speed } \\
\qquad V\left(\mathrm{~cm} \mathrm{~s}^{-1}\right)\end{array}$} \\
\hline & & \multirow{2}{*}{$\begin{array}{c}75>V \geq 25 \\
1-3\end{array}$} & \multirow[t]{2}{*}{$25>V \geq 5$} & \multirow{2}{*}{$\begin{array}{c}\mathbf{v}<5 \\
2\end{array}$} \\
\hline Bryophyte & 9 & & & \\
\hline Submerged spermatophyte & 8 & & & \\
\hline Litter, roots & 7 & & & $1-2-3$ \\
\hline Stones, shingle (250 mm > $\varnothing>25 \mathrm{~mm})$ & 6 & $1-2-3$ & & 1 \\
\hline Coarse gravel (250 mm > $\varnothing>25 \mathrm{~mm})$ & 5 & 3 & 1 & 2 \\
\hline $\begin{array}{l}\text { Emergent spermatophyte of low } \\
\text { substratum }\end{array}$ & 4 & & & 2 \\
\hline Fine sediment (“Mud” $\varnothing<0.1 \mathrm{~mm}$ ) & 3 & & & $1-2-3$ \\
\hline Sand and silt $(\varnothing<2.5 \mathrm{~mm})$ & 2 & 3 & 1 & $2-3$ \\
\hline $\begin{array}{l}\text { Artificial or natural substrates (rock } \\
\text { face, flag, soil) blocs }>\varnothing 250 \mathrm{~mm}\end{array}$ & 1 & 1 & 3 & 2 \\
\hline Algae or clay & 0 & & & \\
\hline
\end{tabular}

\section{Biological Indices}

Various biotic index system have been developed which give numerical scores to specific indicator organisms at particular taxonomic level (ARMITAGE et al., 1983). The following indices were computed.

\section{Shannon-Wiener diversity index}

The Shannon-Wiener diversity index is one of the most widely used species diversity indices for examining overall community characteristics. This diversity measure is based on information theory; simply, the measure of order (or disorder) within a particular system. 
In the present study, this order could be characterized by the number of species and/or the number of individuals in each species, within the sample plots.

$$
H^{\prime}=-\sum_{i=1}^{s}\left(p_{i}\right)\left(\log _{2} p_{i}\right)
$$

where $\mathbf{H}^{\prime}=$ Index of species diversity; $\mathbf{s}=$ Number of species; $\mathbf{p i}=$ Proportion of total sample belonging to ith species; When properly manipulated, it will always result in a diversity value $\left(H^{\prime}\right)$ ranging between 0 (indicating low community complexity) and 4 (indicating high community complexity). This index was performed for all sites.

\section{Jaccard similarity inde}

Using Jaccard's Index with species richness data yields values ranging from 0 to 1 , reflecting the proportion of common species between the two samples. The Jaccard Index was also used which is a measure of similarity. This equation is: $J=W /(A+B-W)$. Where $\mathrm{A}=$ number of taxa in community $\mathrm{A} ; \mathrm{B}=$ number of taxa in community $\mathrm{B} ; \mathrm{W}=$ number of taxa in common. This index was computed using the most sensitive taxa to pollution: Ephemeroptera, Plecoptera and Trichoptera.

\section{ETP index}

The Ephemeroptera, Plecoptera and Trichoptera (EPT) index displays the taxa richness within the insect groups which are considered to be sensitive to pollution and therefore should increase with increasing of water quality. The EPT index is equal to the total number of families represented within these three orders in the sample.

\section{Ratio of ETP/C}

The abundance of EPT and C (Chironomidae) indicates the balance of the community, since EPT are considered to be more sensitive and Chironomidae less sensitive to environmental stress (PLAFKIN et al., 1989). The EPT/C index is calculated by dividing the sum of the total number of individuals classified as Ephemeroptera, Plecoptera, and Trichoptera by the total number of individuals classified as Chironomidae.

\section{Trophic guilds}

The animals were assigned to a particular functional feeding group according to the classification given by MERRITT and CUMMINS (1996).

\section{Biotic index}

The I.B.G.N. biotic index, developed for French streams, is the most appropriate biotic index of water quality for this study. The I.B.G.N. faunal list is restricted to 138 taxa of which 38, in nine indicator groups, are indicators of water quality. Group 9, including Plecoptera, is the most sensitive to pollution; group 1, including worms which can live in highly polluted, turbid waters with little oxygen, is the most tolerant to pollution. The invertebrate samples reflect the biological water quality on a scale of $0-20$, where 0 indicates pollution and 20 no pollution. The I.B.G.N. score for a site depends on both the number of taxa and the indicator groups recorded from the 8 samples.

\section{RESULTS}

\section{Sites description}

Physical and chemical characteristics are given in the Table I. The three brooks are located in similar geomorphologic and hydrological settings. They run through pastoral 
environment with a riparian zone well developed offering important shade. The river beds do not have aquatic macrophytes. Bryophytes are present in all sites. In summer, the surface flow is low, especially for Bellecome (Table II). The water temperatures are cold for all brooks, falling within the range of 12.1 to $14.1^{\circ} \mathrm{C}$. The water is well oxygenated with dissolved oxygen concentration of $8.1,8.8$ and $9 \mathrm{mg} / \mathrm{I} \mathrm{O}_{2}$ for Besque, Holme and Bellecombe, respectively. The streams have similar characteristics in terms of depth and width (Table I). The substrat is relatively diversified for all of them (Table II). Stones are dominant in Holme and Bellecombe ( $70 \%$ of recovery) whereas sand is the substrate the more represented in Besque (60\%).

\section{Taxonomic composition of benthic macroinvertebrates}

The number of individuals and taxa range from 1364 to 2750 , and from 29 to 34 , respectively (Table III). A total of 1502 specimens represented 34 taxa in Holme, with Chironomidae (Diptera: 598 individuals) the dominant taxon. The Diptera, Trichoptera and Ephemeroptera orders were the most family-rich, with 9,7 and 5 families respectively (Table IV). Among the most sensitive taxa were two families of Plecoptera, Leuctridae and Nemouridae. The sample from Bellecombe included 2750 individuals representing 29 taxa. The family of Chironomidae was the most frequently represented, with 2207 individuals. The orders with the greatest family representation were the Diptera and Ephemeroptera with 5 families each (Table IV). Two families of Plecoptera, Leuctridae and Nemouridae were also recorded. The Besque samples contained 1364 individuals with 381 Chironomidae, 312 Gammaridae (Crustacea) and 132 Baetidae (Ephemeroptera) representing 31 taxa. The Diptera had the greatest number of families with 8 , followed by Ephemeroptera with 5 (Table IV). A high diversity of plecopteran families was also recorded with Nemouridae (104 ind.), Leuctricidae (11 ind.), Perlidae (4 ind.) and Perlodidae (1 ind.) (Table IV).

\section{Table III}

Values of biologial and biotic indices used in this study.

\section{Tableau III}

Valeurs des indices biologiques et biotiques utilisés dans cette étude.

\begin{tabular}{lccc} 
& Holme & Bellecombe & Besque \\
\hline Total taxa richness & 34 & 29 & 31 \\
Number of individuals & 1502 & 2750 & 1364 \\
EPT taxa richness & 14 & 11 & 13 \\
EPT abundance & 0.26 & 0.106 & 0.25 \\
EPT/C & 0.76 & 0.13 & 0.9 \\
Shannon diversity & 3.19 & 1.42 & 3.29 \\
IBGN score & 17 & 15 & 17 \\
Water quality & very good & good & very good \\
\hline
\end{tabular}

\section{Biological indices}

Shannon diversity values for the three sites are given in the Table III. This index values ranged from 1.42 to 3.29 for all sites harbouring crayfish. High diversity were observed within Besque and Holme, with a value of 3.29 and 3.19 respectively whereas Bellecombe showed a low diversity with a value of 1.42 suggesting the presence of 
Table IV

Faunal lists of the main invertebrate orders found in the 3 studied sites (IG : Indicator Group for each taxa).

Tableau IV

Listes faunistiques des principaux ordres de macroinvertébrés trouvés dans les 3 stations étudiées (GI : Groupe Indicateur de chaque taxon).

\begin{tabular}{|c|c|c|c|c|}
\hline & IG & Holme & Belle & Besque \\
\hline \multicolumn{5}{|l|}{ PLECOPTERA } \\
\hline Leuctridae & 7 & 20 & 25 & 25 \\
\hline Nemouridae & 6 & 73 & 7 & 3 \\
\hline Perlodidae & 9 & & & 1 \\
\hline Perlidae & 9 & & & 4 \\
\hline \multicolumn{5}{|l|}{ TRICHOPTERA } \\
\hline Brachycentridae & $\mathbf{x}$ & 4 & & \\
\hline Hydropsychidae & 3 & 28 & & 9 \\
\hline Rhyacophilidae & 4 & 17 & 5 & 13 \\
\hline Polycentropodidae & 4 & 4 & 12 & \\
\hline Sericostomatidae & 6 & 4 & 2 & \\
\hline Glossosomatidae & 7 & & & 1 \\
\hline Philopotamidae & 8 & 1 & & \\
\hline Limnephilidae & 3 & 6 & 7 & 3 \\
\hline \multicolumn{5}{|l|}{ EPHEMEROPTERA } \\
\hline Baetidae & 2 & 177 & 99 & 132 \\
\hline Leptophlebiidae & 7 & 6 & 95 & 18 \\
\hline Heptageniidae & 5 & 1 & 16 & 7 \\
\hline Ephemeridae & 6 & 46 & 7 & 12 \\
\hline Ephemerellidae & 3 & 7 & 19 & 28 \\
\hline \multicolumn{5}{|l|}{ DIPTERA } \\
\hline Anthomyidae & & 3 & & \\
\hline Atherycidae & $\mathbf{x}$ & 1 & & 1 \\
\hline Ceratopogonidae & $\mathbf{x}$ & 1 & 3 & \\
\hline Chironomidae & 1 & 598 & 2207 & 381 \\
\hline Dixidae & $x$ & & & 1 \\
\hline Dolichopodidae & $x$ & 1 & & \\
\hline Empididae & $x$ & 10 & & 4 \\
\hline Limoniidae & $\mathbf{x}$ & 18 & 1 & 37 \\
\hline Psychodidae & $\mathbf{x}$ & 16 & & 1 \\
\hline Ptychopteridae & $\mathbf{x}$ & & & 1 \\
\hline Simuliidae & $\mathbf{x}$ & 33 & 3 & 107 \\
\hline Tabanidae & $\mathbf{x}$ & & 4 & \\
\hline
\end{tabular}


dominant taxa. Indeed the most abundant taxa, Chironomidae, comprised $>80 \%$ of the macroinvertebrate assemblage in Bellecombe. The similarity test according to the Jaccard index varied greatly from 0.59 to 0.79 . Holme and Besque have $79 \%$ of common taxa whereas percentages were 70 and 59 with Bellecombe respectively. The ETP values are ranged from 11 to 14. Bellecombe presented the lower number of ETP taxa with 11. Besque and Holme harboured 13 and 14 ETP taxa. The ETP/C ratio was high for Besque and Bellecombe more than 0.76 and low for Bellecombe with 0.13 . The distribution of individuals into functional feeding groups is illustrated in Figure 1. Shredders (mainly Gammaridae), collectors (Hydropsychidae, Simulidae and Chironomidae) and grazers (mainly Baetidae) were well represented in Holme and Besque. Gathering collectors were major components at Bellecombe representing $83 \%$ of total guilds. These consumers were 4 and 6 times more abundant in Bellecombe than Besque and Holme respectively.

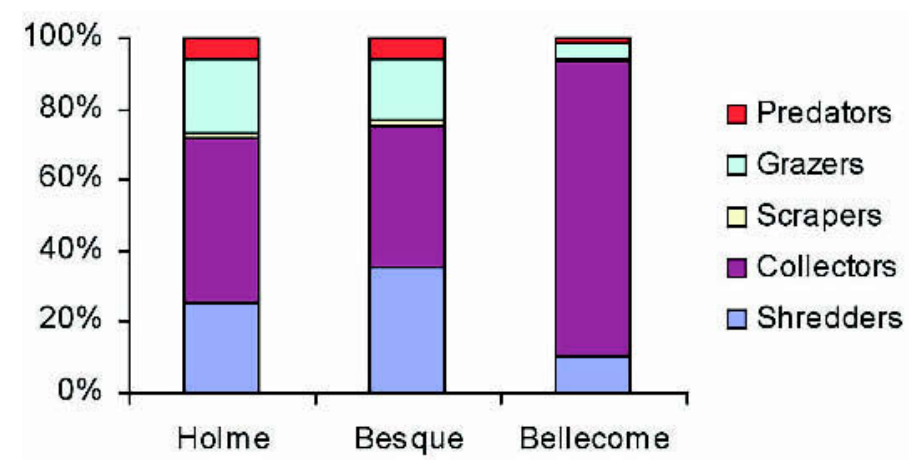

Figure 1

Distribution of trophic guilds within the samples of macroinvertebrates from three studied sites.

\section{Figure 1}

Distribution des guildes trophiques dans les échantillons de macroinvertébrés des trois sites étudiés.

\section{Biotic scores}

I.B.G.N. scores ranged from 15 to 17 (Table III). Following the I.B.G.N. protocol, the Holme and Besque sites had very good water quality whereas Bellecombe had good quality water.

\section{DISCUSSION}

The three sites harbouring the white-clawed crayfish showed good to excellent water quality based on macroinvertebrate sampling, with IBGN scores ranging from 1517 , reflecting an absence or limited impact of the anthropogenic disturbances. These results fell within the ranges of IBGN value generally reported for others French crayfish sites (GRANDJEAN et al., 1996, 2000, 2001; BROQUET, 2002). These other studies confirmed that $A$. pallipes can live in brooks having sub-optimal water quality. The high I.B.G.N. scores seem to indicate that these crayfish population are not actually threatened by degradation of water quality because they are largely higher than the lowest value of 13 estimated for several French brooks (GRANDJEAN et al., 2000, 2001; BROQUET, 2002). Recently, GRANDJEAN (unpublished data) estimated a IBGN score of 10 for a brook harbouring the white-clawed crayfish. This low value is explained both by the low 
taxa diversity and the absence of high indicator groups (9-8-7). At the sampling date, this population seemed to be in good health (no pathogens) with large individuals reflecting a good growth rate (126 mm of total size for the larger male). The occurrence of this species in waters of fair quality was considered surprising. However, four months later, field operations have revealed the disappearance of the population. The brook suffered probably of organic pollution revealed by IBGN before the crash of crayfish population. This dramatic example showed nevertheless that IBGN could provide an warning signal of changes in environment. Moreover, it is suggested that a IBGN score of 10 was not enough to maintain the crayfish population.

The analysis of several metrics such as Shannon diversity and Jaccard indices, ETP taxa richness showed that Besque and Holme have similar faunal characteristics. They have a high macroinvertebrates diversity around 3.2 resulting from equilibrated faunal community. A high number of macroinvertebrates were collected from Bellecombe, but diversity among the taxa was much lower around 1.4. These results could be related to the lack of heterogeneity of habitats. Even if the number of subtrates sampled in this study is relatively similar among brooks, the water flow was more heterogenous in Holme and Besque than in Bellecombe where 7 samples have been made in the same water speed $\left(\mathrm{V}<5 \mathrm{~cm}^{\mathrm{s}-1}\right)$. As reported by STATZNER and HIGLER (1986), the hydrologic regime highly affected the presence of taxa clearly bound to water flow. For example Hydropsychidae was absent in Bellecombe but present in Holme and Besque. The Jaccard index on ETP taxa is ranged from 0.59 between Bellecombe and Besque to 0.79 among Holme and Besque. This high value of similarity indices based on the most intolerant macroinvertebrates in crayfish streams should allow them to be used to select habitats for restocking. This results are not in accordance with the considerable variation in macroinvertebrate community found by GRANDJEAN et al. (2001) among five white-clawed crayfish sites located in PoitouCharentes region. These authors found a lowest Jaccard index around 0.27. However, this low similarity of benthic community could be explained by the difference of water quality among the sites because one presented a IBGN score of 13 and the other 19. In this study, the IBGN score were similar or close for the three sites.

As expected in the headwater stream with well-developed riparian cover as studied here, where detritiral inputs were a significant food source, the shredding macroinvertebrates (Gammaridae, Nemouridae, Limnephilidae) are very abundant in Holme and Besque. This results are in accordance with those obtained by GRANDJEAN et al. $(2000,2001)$ which found percentages of shredders ranged from $37 \%$ to $77 \%$ on six French brooks. A higher density of gathering collectors (Oligochaeta, Chironomidae) was particularly observed in Bellecombe with a ratio EPT/C extremely low compared to the others. According to BIS et al. (2000), a high proportion of collectors is related to the presence of fine particulate organic matter which were probably an important source of energy and nutrients in Bellecombe and therefore strongly influenced the functional organization of macroinvertebrate community. This result suggested that Bellecombe is affected by weak organic pollution which could be related to the low water flow observed in this brook.

In general context to select suitable habitat for restocking, ours results confirmed the hypotheses drawn by GRANDJEAN et al. (2001), namely that the presence of Plecoptera seems to be an excellent criterion for the selection of suitable sites for restocking crayfish. The three sites harboured at least two families of Plecoptera; The heterogeneity of substrates seem to be also a key characteristic of good crayfish habitat (NEVEU, 2000a, b). The high number of both Ephemeroptera and Diptera families also reflected the good quality of sediments. The shredders are well represented in crayfish brook. This result indicates that crayfish habitats are characterized by allochthonous organic production from beyond the edge of the stream. All these streams, near their sources, run through forest which contributes much organic leaf material. To conclude, even if the status of $A$. 
pallipes as bioindicator is questioned (see roundtable), its presence requires nevertheless a preserved environment to human activities with a good quality of water and habitat.

\section{REFERENCES}

AFNOR, 1992. Qualité de l'eau, Recueil des Normes Françaises, 1994. Essai des eaux. Détermination de l'indice biologique global normalisé (IBGN). NF T 90-3, 684-692.

ARMITAGE P.D., MOSS D. WRIGHT J.F., FURSE M.T., 1983. The performance of a new biological water quality score system based on macroinvertebrates over a wide range of unpolluted running water sites. Water Res., 17, 33-47.

BAILLIE J., GROOMBRIDGE B., 1996. IUCN Red list of threatened animals. Gland, Switzerland: IUCN.

BARBOUR M.T., GERRITSEN J., SNYDER B.D., STRIBLING, J.B. 1999. Rapid bioassessment protocols for use in streams and wadeable rivers: Periphyton, Benthic macroinvertebrates, and fish. Second Edition. EPA 841-B-99-002. U.S. Environmental protection Agency. 11 chapters, 4 appendices. (http://www;epa.gov/ owow/monitoring/rbp/).

BIS B., ZDANOWICZ A., ZALEWSKI M., 2000. Effects of catchment properties on hydrochemistry, habitat complexity and invertebrate community structure in a lowland river. Hydrobio., 422/423, 369-387.

BROQUET T., THIBAULT M., NEVEU A., 2002. Distribution and habitat requirements of the white-clawed crayfish, Austropotamobius pallipes, in a stream from the Pays de Loire region, France: an experimental and descriptive study. Bull. Fr. Pêche Piscic., 367, 717-728.

DIEGUEZ-URIBEONDO J., RUEDA A., CASTIEN E., BASCONES J. C., 1997. A plan of restoration in Navarra for the native freshwater crayfish species of Spain, Austropotamobius pallipes. Bull. Fr. Pêche Piscic., 347, 625-638.

GRANDJEAN F., BRAMARD M., SOUTY-GROSSET C., 1996. Distribution and proposal for the conservation of the indigenous freshwater crayfish species, Austropotamobius pallipes pallipes, in a French department. Freshwater Crayfish, 11, 655-664.

GRANDJEAN F., CORNUAULT B., ARCHAMBAULT S., BRAMARD M., OTREBSKY G., 2000. Life history and population biology of the white-clawed crayfish, Austropotamobius pallipes pallipes, in a brook from The Poitou-Charentes region (France). Bull. Fr. Pêche Piscic., 356, 55-70.

GRANDJEAN F., JOUTEUX R., ROPIQUET A., BACHELIER E., BRAMARD M., 2001. Biological water quality assessment in running waters sites harbouring the endangered crayfish, Austropotamobius pallipes based on macroinvertebrates and its potential in habitat selection for restocking. Freshwater Crayfish, XIII, 338-348.

HOLDICH D.M., 2002. Distribution of crayfish in Europe and some adjoining countries. Bull. Fr. Pêche Piscic., 367, 611-650.

KLEMM D.J., LEWIS P.A., FULK F., LAZORCHAK J. M., 1990. Macroinvertebrate field and laboratory methods for evaluating the biological integrity of surface waters. U.S. Environmental Protection Agency. EPA 600/4-90/030, 256 p.

LAZARIDOU-DIMITRIADOU M., ARTEMIADOU V., YFANTIS G., MOURELATOS S., MYLOPOULOS Y., 2000. Contribution to the ecological quality of Aliakmon river (Macedonia, Greece): a multivariate approach. Hydrobiologia, 410, 47-58. 
MANDAVILLE S.M., 2000. Limnology-eutrophication and chemistry, carrying capacities, loadings, benthic ecology and comparative data; Project F-1, soil \& water Conservation society of Metro Halifax. Synopses 1, 2, 3, 13, and 14, 210 p.

MERRIT R.W., CUMMINS K.W., 1996. An introduction to the Aquatic Insects of North America, $3^{\text {rd }}$ edition. Kendall-Hunt Publishing Co., Dubuque, lowa.

NEVEU A., 2000a. Étude des populations d'Austropotamobius pallipes (Crustacea, Astacidae) dans un ruisseau forestier de Normandie. I. Structures démographiques et croissance : stabilité et variété au cours de six années. Bull. Fr. Pêche Piscic., 356, 71-98.

NEVEU A., 2000b. Étude des populations d'Austropotamobius pallipes (Crustacea, Astacidae) dans un ruisseau forestier de Normandie. II. Répartition en fonction de la structure des habitats : stabilité et variabilité au cours de cinq années. Bull. Fr. Pêche Piscic., 356, 99-122.

PLAFKIN J.L., BARBOUR M.T., PORTER K.D., GROSS S.K., HUGHES R.M. 1989. Rapid bioassessment protocols for use in streams and rivers: Benthic macroinvertebrates and fish. U.S. Environmental Protection Agency. EPA 440/4-89/001, 8 chapters, Appendices A-D.

STATZNER B., HIGLER B., 1986. Stream hydraulics as a major determinant of benthic invertebrate zonation patterns. Freshwat. Biol., 16, 127-139.

VERNEAUX J., GALMICHE P., JANIER F., MONNOT A., 1983. Une nouvelle méthode pratique d'évaluation de la qualité des eaux courantes. Un indice biologique de qualité générale (IBG). Annales Scientifiques de I'Université, Besançon, Biologie Animale (4), 3, 11-21.

VIGNEUX E., 1997. Les introductions de crustacés décapodes d'eau douce en France. Peut-on parler de gestion ? Bull. Fr. Pêche Piscic., 344/345, 357-370. 